\title{
Author/Title Index Vol. 12 (1992)
}

The numbers in brackets give the issue in which the article can be found.

Aizawa, A.N., see Katsura, E.

Akeroyd, J., CD-ROM networking

(1) $55-64$

Anwar, M.A., see Iskanderani, A.I.

Basch, R., An end-user view of progress in the information industry

(2) $113-118$

Bénaud, C.L. and S. Bordeianu, OCLC's public service systems: EPIC and FirstSearch

Bearman, T.C., Information transforming society: challenges for the year 2000

(2) $167-176$

Bergman, J.A., see Heminger, A.R.

Bordeianu, S., see Bénaud, C.L.

Brown, P.J., Hypertext in action: some results from an application

(3) $217-224$

Bruïne, R.F.d., The CEC action plan for libraries and IMPACT 2

Buchan, R.L., Quality indexing with computer-aided lexicography

Casewell, I.E., Satellite point-to-multipoint services for information dissemination; opportunities and economics

Cawkell, A.E., Editorial

Cawkell, A.E., Imaging systems and picture collection management: a review

Compton, A.W., Opportunities for CD-ROM information services in Africa

Dyson, M.C., How do you describe a symbol? The problems involved in retrieving symbols from a database

Greenslade, C., Communicating information: options and trends

Gregory, A., The economics of the new technology of delivery systems

Hara, S., see Katsura, E.

Harrison, L.D., Implementing the MALIMET Thesaurus on TRIP/TDBS

Hein, M., National library policy in Community wrapping

Heminger, A.R., P.A. Hommel and J.A. Bergman, Considerations for using an expert system in the guardianship process for adults

Hommel, P.A., see Heminger, A.R.

Iskanderani, A.I. and M.A. Anwar, Automated bilingual circulation system using PC local area networks

Katsura, E., A. Takasu, S. Hara and A.N. Aizawa, Design considerations for capturing an electronic library

Kumar, R., B.R. Nagar, R.N. Neogi and M. Srivastava, Status report of Indian scientific institutions/universities in the field of agricultural sciences on the basis of Indian Science Abstracts, 1990

Martini, G., Business information as a strategic factor in company development

Muirhead, G.A., System management in UK libraries: some preliminary findings of a survey

Nagar, B.R., see Kumar, R.

Neogi, R.N., see Kumar, R.

Nkereuwem, E.E., The correlation between job satisfaction, job attitudes and work behaviour among the staff in academic libraries in Nigeria

(1) $41-54$

(3) $195-204$

(1) $77-84$

(1) $23-40$

(1) $1-2$

(4) $301-325$

(3) $283-290$

(1) $65-76$

(3) $247-252$

(2) 157-166

(4) $327-343$

(3) $225-234$

(1) $9-22$

(2) $141-156$

(2) $99-112$

(2) 119-124

(1) $3-8$

(2) $177-194$

(3) $253-262$

0167-5265/93/\$06.00 @ 1993 - Elsevier Science Publishers B.V. All rights reserved 
Nweke, K.M.C., Training needs and methods of training in information technology for Nigerian special library services

Oppenheim, C., Legal issues for information professionals. Part II. The new European Draft Directive on Database Copyright

Priestley, J., The SOLSTICE Project: satellite television and audioconferencing in continuing professional development for LIS staff

Sacks, L.R., Opportunities for information providers within the emerging world markets of the Pacific Rim

Srivastava, M., see Kumar, R.

Stephenson, G.A., Open information interchange

(4) 291-299

Suomi, R., Reception of case tools - a case study

(3) $275-282$

(3) $263-274$

(2) $125-130$

(3) $235-246$

(1) $85-98$

Takasu, A., see Katsura, E.

Trier, G.M.v., The future of libraries and information services: report of a Delphi study

(3) $205-216$

Wakeham, M., The information seeking behaviour of nurses

(2) $131-140$

Watson, M., Gateshead Libraries and Arts Service: making information accessible

(4) $345-347$ 